\title{
Stable forest carbon stocks support current assumption of biogenic carbon neutrality in the case of European-manufactured beverage cartons
}

\author{
Odhran S. O'Sullivan $^{1,2}$ • Lisa Hopkinson ${ }^{1}$ - Martha E. Crockatt ${ }^{1,3}$ • Paul Laird ${ }^{1}$. \\ Daniel P. Bebber ${ }^{1,4}$
}

Received: 29 August 2014 / Accepted: 23 October 2015 /Published online: 11 November 2015

(C) The Author(s) 2015. This article is published with open access at Springerlink.com

\begin{abstract}
Purpose Life cycle assessments (LCAs) of forest-based products, such as beverage cartons, generally demonstrate lower greenhouse gas emissions than fossil fuel-based alternatives and often contain the implicit assumption that removal of carbon dioxide $\left(\mathrm{CO}_{2}\right)$ by a growing forest and emission of $\mathrm{CO}_{2}$ at the end of a product's life cancel each other out such that the net emission is zero. This study aims to test the validity of this assumption of biogenic $\mathrm{CO}_{2}$ neutrality in relation to beverage cartons by examining whether carbon stocks of the source forests are stable. The fact that over $95 \%$ of the cartonboard used in their manufacture is sourced from the boreal forests of Sweden and Finland provides a scenario with a straightforward relationship between forest and product thus avoiding issues surrounding the complexities of global supply chains. Methods The reviewed LCAs conclude that beverage cartons have lower greenhouse gas emissions than alternatives, although non-forest-derived components such as plastic caps and aluminium laminate often contribute disproportionately to those emissions. We discuss issues surrounding the
\end{abstract}

Responsible editor: Matthias Finkbeiner

Odhran S. O’Sullivan

odhran.osullivan@gmail.com

1 Earthwatch Institute (Europe), Mayfield House, 256 Banbury Road, Oxford OX2 7DE, UK

2 Department of Animal and Plant Sciences, University of Sheffield, Western Bank, Sheffield S10 2TN, UK

3 Environmental Change Institute, School of Geography, University of Oxford, Oxford OX1 3QY, UK

4 Department of Biosciences, College of Life and Environmental Sciences, University of Exeter, Exeter EX4 4QD, UK assumption of biogenic $\mathrm{CO}_{2}$ neutrality and explore the factors that influence carbon stocks in boreal forests that supply much of the raw material for beverage cartons.

Results and discussion An analysis of published rates of carbon sequestration in the managed forests of Finland and Sweden reveals that forest carbon is stable under current harvest rates. This lends support to the assumption of biogenic $\mathrm{CO}_{2}$ neutrality in the case of beverage cartons produced from these forests. We conclude that greenhouse gas emissions would not change if an LCA included forest carbon. However, future forest dynamics and thus carbon stocks are predicted to alter in response to climate change, for example, which will have knock on effects for greenhouse gas emissions from packaging derived from forests.

Conclusions This review combines current thinking on inclusion of forest carbon in LCAs with an analysis of issues that will influence carbon stocks in managed forests. Although current assumptions of biogenic $\mathrm{CO}_{2}$ neutrality are valid in the case of European-manufactured beverage cartons, we argue that this assumption needs to be explicitly addressed in LCAs. While there is no accepted methodology for integrating biogenic forest carbon uptake into LCA, our assessment of current trends in forest carbon stocks allows for assumptions of biogenic $\mathrm{CO}_{2}$ neutrality to be tested, although our approach may not be practical for more complex supply chains.

Keywords Beverage cartons - Biogenic carbon - Carbon debt $\cdot$ Climate change $\cdot$ Finland $\cdot$ Forestry $\cdot$ LCA $\cdot$ Sweden

\section{Introduction}

The use of forest products in packaging is expected to have lower greenhouse gas emissions than fossil fuel-based alternatives, mainly due to sequestration of carbon in the forest. 
The climate change impact of a particular product or process is generally quantified by a life cycle assessment (LCA) that assesses potential environmental impacts across its entire lifecycle from raw material extraction, to manufacturing, packaging, distribution, use and end of life (Hellweg and Milà i Canals 2014). In the case of forest-based products, LCA studies typically assume that the removal of carbon dioxide $\left(\mathrm{CO}_{2}\right)$ by a growing tree and emission of $\mathrm{CO}_{2}$ at the end of a product's life cancel each other out such that the net emission of biogenic $\mathrm{CO}_{2}$ (derived from non-fossil and biodegradable organic matter) is effectively zero (Rabl et al. 2007). However, there are a growing number of studies which suggest that biogenic $\mathrm{CO}_{2}$ is not necessarily neutral (Holtsmark 2013; Helin et al. 2013) due to $\mathrm{CO}_{2}$ losses associated with harvesting, for example. Thus, the net effect of a growing forest together with emissions associated with harvesting and associated processes need to be explicitly accounted for in an LCA.

In this literature review, we address the question of whether beverage carton packaging made from forest products has lower or higher greenhouse gas emissions than alternative packaging options, once biogenic $\mathrm{CO}_{2}$ is taken into account, and review current research on carbon sequestration in European forests. This study updates previous reviews of beverage carton LCAs (von Falkenstein et al. 2009; von Falkenstein et al. 2010) and examines recent LCAs that assess the greenhouse gas emissions, among other environmental indicators, of European beverage cartons in comparison with alternatives. Beverage cartons are short-lived forest products that consist of 75 $90 \%$ cartonboard, a material produced from virgin wood fibre harvested from forests. In Europe, the raw material is sourced from managed boreal forests of Finland and Sweden for manufacture of over $95 \%$ of beverage cartons in Europe (ACE 2013a, b). The examination of beverage cartons manufactured in Europe avoids the complexities of the range of forest and wood fibre types found in globalised supply chains, sidestepping an important criticism of LCA analyses in their use of simplistic forest carbon models (Newell and Vos 2012), providing a scenario with an uncomplicated relationship between forest and product that allows for a simplified analysis of whether inclusion of biogenic $\mathrm{CO}_{2}$ will alter the conclusions of beverage carton LCAs. We conduct a literature review to compare the LCA greenhouse gas emissions of beverage cartons versus fossil fuel-based alternatives, review the evidence on how best to integrate forest carbon into LCAs to achieve a true "cradle to grave" assessment of beverage carton packaging, test whether assumptions of biogenic $\mathrm{CO}_{2}$ neutrality are true in the case of beverage cartons by examining trends in carbon stocks of the source forests, and discuss how assumptions surrounding the issue of biogenic $\mathrm{CO}_{2}$ in LCAs may change under future climate change.

\section{Life cycle assessments-beverage cartons compared to alternatives}

For this review, LCA studies on beverage cartons were selected for detailed consideration based on the criteria that the study (1) follows current LCA methodology (i.e. ISO 14040 and 14044-ISO 2006a, b) and was conducted post-2006 using the latest revision of ISO standards, (2) considers the global warming potential (GWP) of the product in terms of greenhouse gas emissions over a fixed time period, (3) compares beverage cartons to an alternative type of packaging, (4) was conducted in Europe, and (5) provides quantitative information in an accessible format (e.g. data tables). Although the revision of LCA methodology standards in 2006 did not involve significant content changes, the use of a convenient post-2006 cutoff point avoids many of the studies already reviewed in previously published studies (von Falkenstein et al. 2009; von Falkenstein et al. 2010). Note that, due to the rarity of recent beverage carton LCAs, two studies (Detzel et al. 2008; Labouze et al. 2008) covered by von Falkenstein are also reviewed for this study. The selected studies are from a range of European locations and cover a wide range of assumptions including different boundary conditions and end-of-life treatments and assumptions, as well as different packaging types, sizes and beverages (predominantly milk and juice) (Table 1). The studies considered numerous beverage carton types which can include a thin layer of polyethylene (for chilled cartons) or thin layers of aluminium and polyethylene for longer life products (James 2010) with optional plastic openings of high-density polyethylene (HDPE). All of the studies considered were attributional LCAs that assess the environmentally relevant flows of a product system rather than consequential LCA that describes how environmentally relevant flows change in response to possible decisions made (Curran et al., 2005). While the majority of the studies were full LCAs, which looked at a range of environmental indicators, our analysis only considered the greenhouse gas emissions (expressed in units of $\mathrm{CO}_{2}$ equivalents) over the lifetime of the product.

Despite the variation in boundary conditions and assumptions, the selected LCA studies concluded that beverage cartons have lower greenhouse gas emissions than the alternative packaging types considered (Table 1). This is in line with an earlier meta-analysis of 22 LCA studies from 1997-2008 (von Falkenstein et al. 2009; von Falkenstein et al. 2010). Although most studies found beverage cartons to have the lowest greenhouse gas emissions, two studies found slightly lower emissions for an alternative non-renewable resource-derived packaging, i.e. 


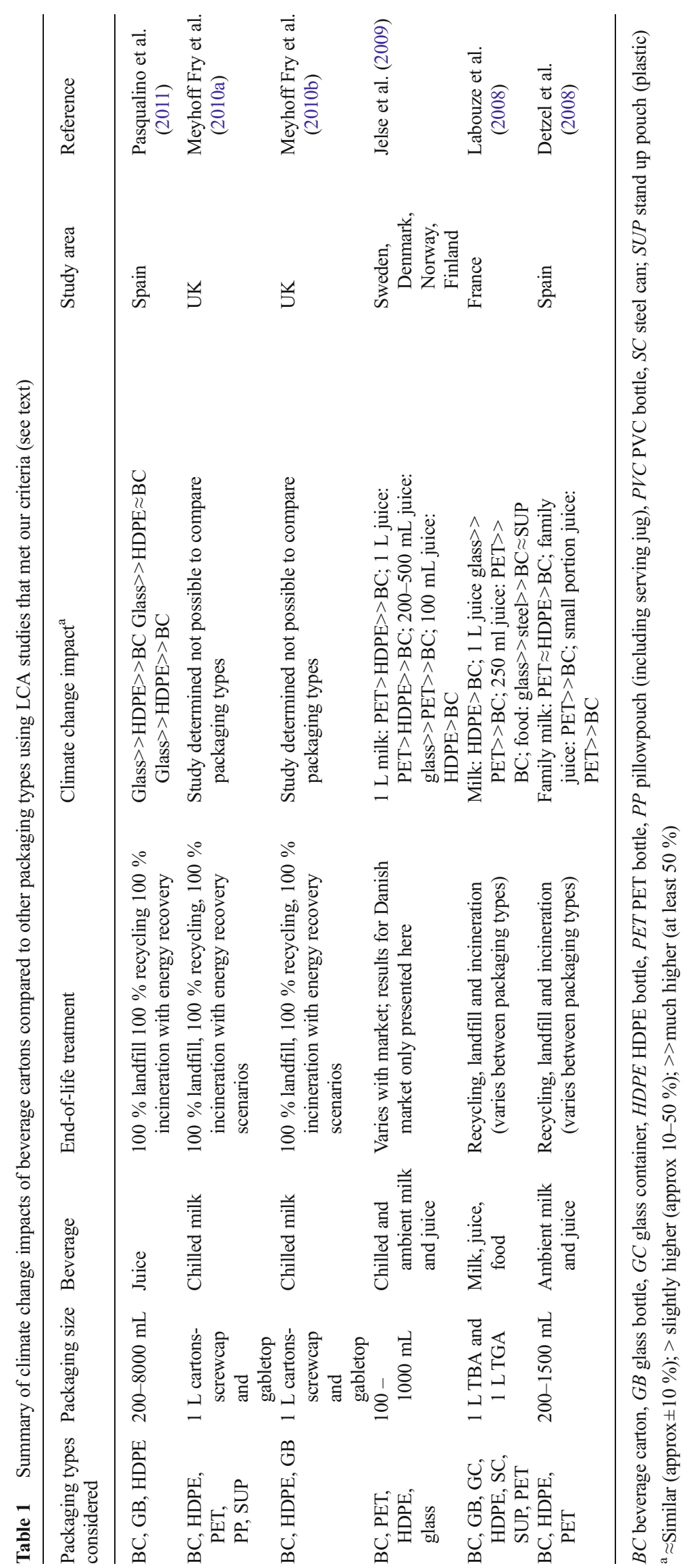


$400 \mathrm{~mL}$ plastic stand-up-pouch food containers (Labouze et al. 2008) and 1.5 L HDPE milk containers (Detzel et al. 2008), and another came to no firm conclusion due to difficulties comparing different packaging types (Meyhoff Fry et al. 2010a, b). In the studies reviewed, the greenhouse gas emissions of beverage cartons were generally much lower $(>50 \%)$ than glass, occasionally much lower and generally lower (10-50\%) than PET bottles, and generally lower (10-50\%) than HDPE bottles. The high energy consumption of glass (Labouze et al. 2008) and plastic production (Jelse et al. 2009) is a key factor contributing to their higher emissions. Thus, all other things being equal, the LCAs reviewed indicate that beverage cartons have lower emissions relative to fossil fuel-derived packaging whose end-of-life $\mathrm{CO}_{2}$ emissions are not offset by any removals.

Production of raw materials and the beverage cartons themselves were shown to contribute the majority of the greenhouse gas emissions (Detzel et al. 2008; Labouze et al. 2008; Meyhoff Fry et al. 2010b, a; Pasqualino et al. 2011), with the most basic 'brick' beverage carton having the lowest emissions (Jelse et al. 2009). The use of plastic and aluminium components of the beverage carton contributed disproportionately to emissions. For example, plastic cap production accounted for nearly $25 \%$ of the lifetime greenhouse gas emissions for beverage cartons in one LCA (Meyhoff Fry et al. 2010b). Similarly, aluminium laminate, although a small fraction of the beverage carton weight, made a relatively high contribution to greenhouse gas emissions due to the high energy intensity of virgin aluminium production (Jelse et al. 2009; Detzel et al. 2008), more than either the carton board or the plastic components (Detzel et al. 2008; Labouze et al. 2008). Greenhouse gas emissions could be minimised through the use of lightweighting to reduce the weight of packaging (James 2010; Meyhoff Fry et al. 2010a, b) or through the use of polyamide instead of aluminium as a barrier layer (Wellenreuther et al. 2012).

The LCA studies reviewed indicate that over a wide range of conditions, end-of-life treatments and other key assumptions, beverage cartons have lower greenhouse gas emissions than alternative packaging materials such as glass bottles, PET bottles and HDPE bottles. Note these findings on greenhouse gas emissions do not necessarily apply to other environmental impacts. Some studies found that beverage cartons had higher aquatic eutrophication impacts than plastic alternatives (e.g. Detzel et al. 2008; Xie et al. 2011), for example, highlighting the importance of broader environmental issues in any policy reviews on alternative packaging. Furthermore, the reviewed LCAs do not quantify changes in biogenic $\mathrm{CO}_{2}$ and refer only to fossil carbon and biogenic non- $\mathrm{CO}_{2}$ emissions. This issue of biogenic $\mathrm{CO}_{2}$ is explored in the next section.

\section{LCA and biogenic carbon neutrality}

LCA has strengths and weaknesses. It provides an objective and systematic means of assessing a wide range of environmental impacts for a product or service, but the results are very specific to the methodology and assumptions of each study. Each study defines system boundary conditions that refer to the processes in the products' life cycle used to determine the total climate change impact of the product. Several detailed reviews of LCA studies on paper and wood products have identified a number of key assumptions that can significantly affect the results of LCAs associated with forestry products (Villanueva and Wenzel 2007; Sathre and O'Connor 2010; Gaudreault and Vice 2011). These include many assumptions that also apply to fossil fuel products, e.g. where the system boundary is drawn, what method is used to allocate recycling loads/benefits, what avoided energy or materials are substituted for, various waste treatment assumptions such as rates of decomposition in landfill, as well as assumptions that are specific to paper- and wood-based products such as the treatment of biogenic $\mathrm{CO}_{2}$. For example, including wood 'saved' by recycling, attributing $100 \%$ of recycling benefits to the virgin material replaced or comparing avoided energy at the end of life with electricity generated with coal or gas may all significantly impact on the outcome.

While LCA studies may generate uncertain outcomes, the overall results still allow for broad conclusions to be drawn (Brandão et al. 2012) making LCA a useful tool for comparative studies where assumptions can be standardised. For paper- and wood-based products, it is generally assumed that biogenic $\mathrm{CO}_{2}$ is neutral, whereby the removal of carbon by growing forest biomass and emission of carbon at the end of a product's life cancel each other out so that the net effect of uptake and emission is assumed to be zero (Rabl et al. 2007). This assumption is rarely challenged even though there is emerging evidence that it may not always be true in practice and could significantly impact the estimated lifetime greenhouse gas emissions of a product. For example, all the studies reviewed (Table 1) have assumed biogenic $\mathrm{CO}_{2}$ neutrality while emissions of other biogenic carbon compounds (e.g. methane and carbon monoxide) at end of life such as through decomposition in landfill, as well as $\mathrm{CO}_{2}$ emissions from fossil fuel use, are explicitly estimated in LCAs.

A key issue concerning biogenic $\mathrm{CO}_{2}$ neutrality is the concept of a 'carbon debt' originally applied in relation to biofuels, but applicable to any wood-based product as it requires consideration of emissions associated with harvesting and any changes in forest carbon stocks brought about by altered management. Clearing a forest or grassland to plant crops for biofuel production can release large amounts of trapped carbon, an upfront carbon debt, which 
might be repaid over time via emissions avoided by using biofuels to replace fossil fuels (Searchinger 2010). In the case of managed forests that are regularly harvested, but not cleared, an analysis shows that increases in wood harvesting rates to produce bioenergy could involve a loss in forest carbon stocks that may take many years to "payback' through forest regrowth even taking into account the fossil fuel emissions avoided by the use of bioenergy (Manomet Center for Conservation Sciences 2010; Zanchi et al. 2010; Cherubini et al. 2011; EEA Scientific Committee 2011; Hudiburg et al. 2011; McKechnie et al. 2011; Holtsmark 2012; Schulze et al. 2012). Thus, there is a trade-off between a more intensive harvesting of forests and minimising reductions in total forest carbon stocks (Holtsmark 2012). Earlier harvest times and shorter rotation periods lead to younger stands and lower forest carbon stocks compared to forests with more mature trees and, therefore, greater carbon emissions to the atmosphere in the short to medium term. Various factors influence the 'payback period' for the carbon debt including the use of thinnings, residues or additional fellings (Zanchi et al. 2010); wood from slow growing boreal or faster growing temperate forests (Holtsmark 2012); alternative uses of biomass (McKechnie et al. 2011); future forest management and natural disturbances (Manomet Center for Conservation Sciences 2010); and changes in other forest carbon pools (James 2012).

Despite calls for the explicit accounting for biogenic $\mathrm{CO}_{2}$ emissions and removals (Rabl et al. 2007), most LCAs assume that forest carbon stocks remain stable (i.e. neutral biogenic $\mathrm{CO}_{2}$ ). An LCA for a wood-based product needs to address the increase or decrease in carbon stocks from the forest together with fossil and biogenic carbon greenhouse gas emissions resulting from production, use and disposal of that product. If it is assumed that net biogenic $\mathrm{CO}_{2}$ emissions are zero, then this assumption needs to be made explicit with reference to the forest origin, to ensure transparency and whether the assumption of stable forest carbon stocks is reasonable. Ideally for the purpose of an LCA, data would be available on carbon stock changes from individual commercial forests, but this may be difficult in practice when products are typically sourced from multiple forests as well as the lack of traceability for non-certified wood products.

\section{Boreal forest carbon}

The inclusion of biogenic $\mathrm{CO}_{2}$ requires an understanding of factors that influence managed forests. Thus, it is important to examine what factors influence carbon stocks of boreal forests that supply the cartonboard used for beverage carton manufacture in Europe and influence their life cycle greenhouse gas emissions.

\subsection{Boreal forest carbon stocks}

Boreal forests, found in high latitudes across North America, Eurasia and Fennoscandia, exhibit relatively low rates of carbon sequestration (Pregitzer and Euskirchen 2004; Nabuurs et al. 2008) due to their slow growth. However, the slow decomposition in the soil, dead wood and leaf litter (Burton et al. 2010) makes them an important global carbon stock accounting for roughly $32 \%$ of the total forest carbon (Pan et al. 2011). The soil is the largest carbon pool in boreal forests, roughly three to six times the size of the aboveground biomass carbon pool (Dixon et al. 1994; Kasischke et al. 1995; Pan et al. 2011).

In Finland and Sweden, over $92 \%$ of the largely boreal forest area consists of managed forests (Ylitalo 2012; Wigrup 2012), with protected forests making up the remaining $8 \%$. Although there is no significant difference in carbon sequestration rates reported for managed and unmanaged boreal forests (IPCC 2006), the carbon stocks of unmanaged boreal forests are larger than managed forests per hectare due to higher stand density, more biomass and greater litter production (Karjalainen 1996; Thornley and Cannell 2000; Finér et al. 2003; Garcia-Gonzalo et al. 2007; Luyssaert et al. 2008).

\subsection{Current forest carbon trends in Finland and Sweden}

In the case of Finland and Sweden, national inventory data provides estimates of total carbon in these predominantly managed forests. Total national sequestration rates (a figure that includes all forest carbon pools and not just changes in biomass) have been increasing since 1990 in Finland, with a slight downward trend in Sweden over the same time period (SEPA 2012; Statistics Finland 2012), resulting in a slight upward trend for the two nations combined (Fig. 1). These figures are equivalent to a mean sequestration rate of $0.38 \mathrm{t} \mathrm{C} \mathrm{ha}^{-1}$ year $^{-1}$ in 2010 for the boreal forests of Finland and Sweden, similar to other reported rates (FAO 2010), but slightly lower than the global boreal forest rate of $0.45 \mathrm{t} \mathrm{C} \mathrm{ha}^{-1}$ year $^{-1}$ (Pan et al. 2011). The calculated rate for Finland and Sweden corresponds to an annual increase in total forest carbon of $0.9 \%$, which confirms that carbon stocks of the forests used to supply the raw material for beverage cartons are growing, even with current rates of harvest. This is in line with a wider European study that reported forest growth was greater than removals from forests for the past 20 years (Köhl et al. 2011). The fact that these forest carbon stocks are currently stable suggests that established management practices have not led to increases in the 'carbon debt' discussed earlier. 


\subsection{Future climate change impacts and potential management responses}

Climate change impacts on boreal forests are difficult to predict. Increased levels of $\mathrm{CO}_{2}$ in the atmosphere may bring about increased rates of photosynthesis and net carbon sequestration (Smith et al. 2006; Hyvönen et al. 2007). Other studies suggest the opposite as forests may not be carbon limited and so increased atmospheric concentrations will not necessarily lead to enhanced growth (Millard et al. 2007). Climate warming has already resulted in some Russian boreal forests becoming net sources of $\mathrm{CO}_{2}$ (Milyukova et al. 2002), as losses due to increased soil and plant respiration were greater than any gains in sequestration due to enhanced photosynthesis. There is also an additional risk of increased fire frequency and insect outbreak disturbances associated with climate change (Kurz et al. 2008; Fischlin et al. 2009). These disturbances can lead to lower boreal carbon stores and increased emissions (Lucier et al. 2009). Currently, there is no firm consensus in the literature of what the net outcome of climate warming will be for boreal forest carbon stocks (DeLuca and Boisvenue 2012), although climate change is likely to lead to significant carbon losses in the boreal zone from peatland soils due to melting of permafrost (Zimov et al. 2006).

Forest management can protect forest carbon in three key ways: conserving and increasing forest area, maintaining and increasing net carbon sequestration rates, and reducing fossil fuel use and disturbance impacts of management practices (EUSTAFOR 2012). For example, disturbances associated with site preparation can lead to a net loss of soil carbon, (Jandl et al. 2007) while relatively short rotation times may not be optimal from an overall carbon management point of

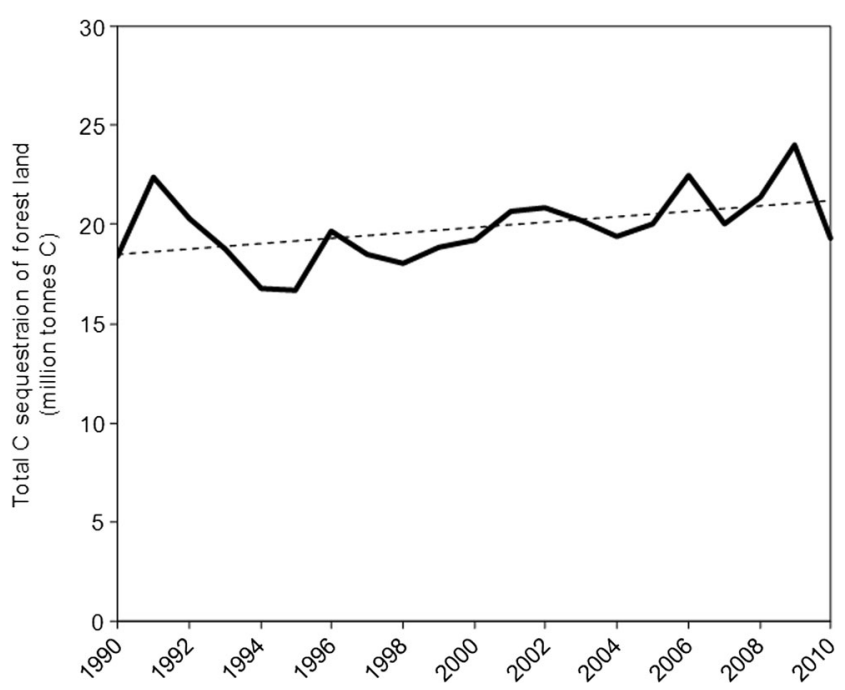

Fig. 1 Total net sequestration of carbon in forest lands in Finland and Sweden (solid line) (data from Statistics Finland 2012; SEPA 2012). Dashed line shows significant $(p<0.05)$ linear correlation between carbon stocks and year from 1990 to $2010\left(r^{2}=0.2196\right)$ view (Schulze et al. 1999; Luyssaert et al. 2008). Management practices such as longer rotation periods and altered thinning regimes can help maintain and enhance forest carbon stocks (Garcia-Gonzalo et al. 2007; Grant and Nalder 2000; Thurig and Kaufmann 2010; Gelman et al. 2013). This has to be balanced against relatively low rates of carbon sequestration in boreal forests (Pregitzer and Euskirchen 2004; Nabuurs et al. 2008) which means there may not be much capacity to expand this carbon sink through enhanced management (Bradshaw et al. 2009; DeLuca and Boisvenue 2012).

\section{Integrating forest carbon into LCAs}

While the reviewed LCAs show that beverage cartons, derived from a renewable resource, generally have a lower climate change impact than alternatives, this conclusion is based on the assumption that biogenic $\mathrm{CO}_{2}$ is neutral. In reality, the issue ultimately depends on the balance between forest carbon removals through harvesting and carbon absorbed by the growing forest over a fixed amount of time (Fig. 2). This balance will also be influenced by management changes that lead to younger stands and lower carbon stocks, losses due to disease or drought as well as climate change impacts.

\subsection{Integrating biogenic $\mathrm{CO}_{2}$ into LCAs of forest products}

There have been a number of attempts to integrate the complex relationship between the biological carbon cycle (the forest ecosystem) with the industrial carbon cycle (forest products) (e.g. Schlamadinger and Marland 1996; Apps et al. 1999; Côté et al. 2002; Gower 2003; White et al. 2005; Profft et al. 2009; Pingoud et al. 2010; Eriksson et al. 2010; McKechnie et al. 2011), but the complexities of forest carbon stocks and exchanges, the globalisation of forest product supply chains as well as the diversity of products from a given forest make this a difficult task (Profft et al. 2009). LCAs do not aim to assess the complexity of forest carbon dynamics, and so approaches to include the carbon emission and sequestration of managed forests remain controversial (Helin et al. 2013), leading to calls for stronger research links between academics working on forestry carbon models and those conducting LCAs of forest products (Newell and Vos 2012).

We found only one study relevant to beverage cartons that accounts for biogenic $\mathrm{CO}_{2}$ in its analysis using a method that explicitly includes estimates of forest carbon sequestration (CEPI 2007) applied to a carbon footprinting study of cartonboard (Eriksson et al. 2010). This study found a reduction of $65 \%$ in the greenhouse gas emissions (from 1127 to $397 \mathrm{~kg} \mathrm{CO}_{2}$ eq./tonne cartonboard) if the potential offset from net $\mathrm{CO}_{2}$ sequestration from the living biomass of the managed European forests from which the raw material is harvested was included. This highlights the fact that the greenhouse 


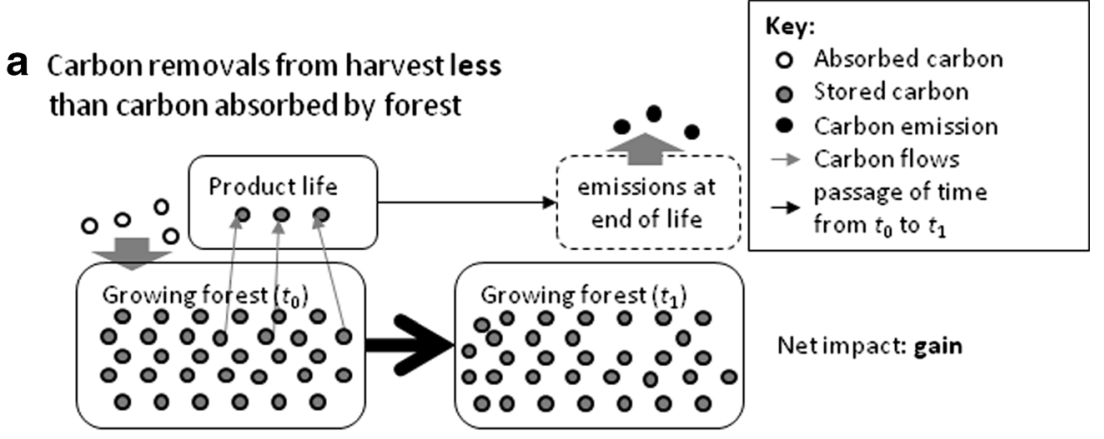

\section{b Carbon removals from harvest greater than carbon absorbed by forest}

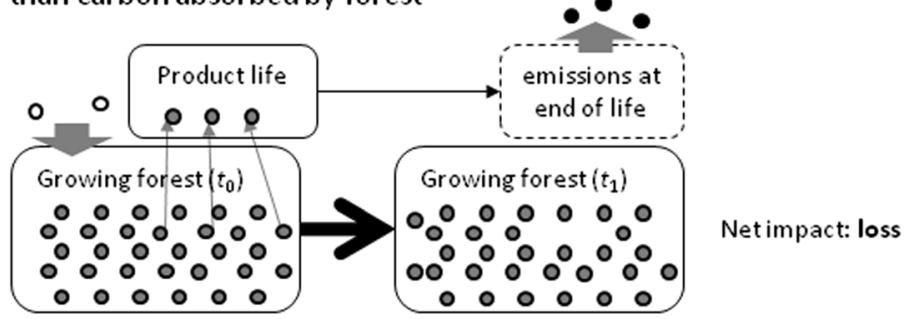

Fig. 2 Simple schematic illustrating net impact of the inclusion of forest carbon under two different scenarios of a $\mathbf{a}$ growing or $\mathbf{b}$ shrinking forest carbon pool after harvest is taken into account. Note that units are arbitrary and do not represent measured changes in carbon. In this schematic, the amount of carbon harvested for use in the forest product is the same, and although the net carbon sequestration is low compared to the total carbon stocks in both forests, forest A has absorbed twice as many units of carbon as forest B. Note that the schematic does not consider further complexities of forest carbon dynamics that may influence continuing absorption of carbon at $t_{1}$, such as potentially increased net carbon sequestration due to thinning

'carbon debt' associated with harvesting discussed earlier will challenge current assumptions of biogenic $\mathrm{CO}_{2}$ neutrality in this specific case. This strengthens the case for beverage cartons as a lower carbon packaging alternative.

However, there is no universally accepted methodology for how best to account for biogenic $\mathrm{CO}_{2}$ in an LCA of a forest product and it is not currently possible to link changes in forest carbon stocks with a specific forest-based product. Further investigation is required with emphasis on collecting data on changes in carbon stocks in managed forests and improving the traceability of forest-based products to specific forests so as to better enhance the precision of LCAs with respect to biogenic $\mathrm{CO}_{2}$. In this study, we have used published regional estimates as to assess whether the carbon stocks of source forests for cartonboard are increasing or decreasing so as to test the assumption of biogenic $\mathrm{CO}_{2}$ neutrality. Ideally, the wood used for the forest product should be traced back to the source forest through chain of custody certification, for example, and these forests should provide data from a quick carbon stock assessment protocol for foresters that is repeated on a regular basis such as one recently developed for tropical forests (Berenguer et al. 2015). The important point is that any changes (positive or negative) in carbon stocks through harvesting need to be taken into account in an LCA. If a forest product is being harvested from an unsustainably managed forest in terms of forest carbon, such that net forest carbon stocks are decreasing due to harvest removals that are not 
replaced by the growing forest, this should be reflected in its lifetime greenhouse gas emissions. Equally, the carbon gains in a well-managed forest should also be accounted for, potentially leading to lower greenhouse gas emissions for a forest product.

\subsection{Future treatment of biogenic carbon in LCA}

It is clear that LCAs should not make the implicit assumption of biogenic $\mathrm{CO}_{2}$ neutrality, but instead explicitly include biogenic $\mathrm{CO}_{2}$ removals and emissions in any LCA involving forest products. The best method to properly account for biogenic $\mathrm{CO}_{2}$ is still open to debate. The relatively simplistic method used by Eriksson et al. (2010) that apportions part of the annual net sequestration from a region's forest to a forest product is likely to reduce the greenhouse gas emissions of beverage cartons since the forests of Sweden and Finland are stable in their total forest carbon stocks. However, this only applies to European-manufactured beverage cartons because these forests supply the vast majority of the raw material for manufacture (ACE 2013a, b). These issues become much more complicated for non-European beverage cartons due to globalised supply chains which may involve a range of forest types and different forest management systems.

It has been noted in a meta-analysis that none of the LCAs on beverage cartons covered the origin of wood resources and that 'in the future this issue could become crucial for the credibility of LCA results for product systems based on biomass resources' (von Falkenstein et al. 2010). Future LCAs should include information on whether the paperboard is certified by bodies such as the Forest Stewardship Council (FSC) which often includes chain of custody certification (FSC 2013) and other information on the origin of wood (as well as the origin of non-wood resources like petroleum and metals) (von Falkenstein et al. 2010).

In practice, this would mean that the origin of wood for a product is known, and if it can be demonstrated that the carbon stocks in those forests are stable, then it is reasonable to assume that biogenic $\mathrm{CO}_{2}$ is neutral thus any emissions at end of life can be effectively discounted. However, where the carbon stocks in the forest are increasing or decreasing (net sequestration is negative or positive), then this should be included in the LCA. In cases where the wood origin is unknown, then a sensitivity analysis should be conducted, based on a worstcase scenario. This implies a need for much better data on wood origin and forest carbon stock changes than probably exists at present. Country National Inventory Reports for the United Nations Climate Change Convention could be used as an approximation, although adjustment is necessary for any country with a high proportion of natural or protected forests as carbon sequestration by these forests should not be used to credit a product's footprint.

\section{Conclusions}

The comparative LCA studies of different packaging materials reviewed all concluded that the greenhouse gas emissions of beverage cartons are generally lower than alternatives. While use of plastic openings and the aluminium content of beverage cartons have a disproportionate impact on the lifetime greenhouse gas emissions, the production of raw materials and the beverage cartons themselves contribute the majority of the emissions.

An LCA for a wood-based product needs to explicitly address assumptions of biogenic $\mathrm{CO}_{2}$ neutrality using data on forest carbon stocks, as well as any greenhouse gas emissions resulting from production, use or disposal of that product. The reviewed LCAs assumed that net biogenic $\mathrm{CO}_{2}$ emissions were zero and did not explicitly estimate the removal of carbon by the growing forest or emissions of $\mathrm{CO}_{2}$ at the end of the product's life. However, the fact that the individually managed certified forests of Finland and Sweden are likely to be net carbon sinks would support the conclusions from the comparative LCA studies and suggests the greenhouse gas emissions of European-manufactured beverage cartons may be even lower than estimated once biogenic $\mathrm{CO}_{2}$ is taken into account. Thus, an assessment of changes in carbon stocks in the forests that supply the raw material for the forest product offers a logical way to assess the key assumption of biogenic $\mathrm{CO}_{2}$ neutrality. If the source forests can be demonstrated to be stable in terms of their carbon stocks, as is the case for the boreal forests of Sweden and Finland that supply the cartonboard for beverage cartons in Europe, then the assumption of biogenic $\mathrm{CO}_{2}$ neutrality is valid. For more complex supply chains, this approach may not be practical, although it would sidestep the fact that there is still no accepted methodology for integrating biogenic $\mathrm{CO}_{2}$ emissions into LCA and instead allow the key assumption of biogenic $\mathrm{CO}_{2}$ neutrality to be assessed. In cases where the wood origin is unknown, then a sensitivity analysis should be conducted, based on a worst-case scenario. This will require better data on the origin of wood and improved data on changes in forest carbon stocks/net sequestration. Country National Inventory Reports for the United Nations Climate Change Convention can be used as an approximation with appropriate adjustment where a country has a high proportion of natural or protected forests-as carbon sequestration by these forests should not be used to credit a product's footprint.

Future climate change impacts on forests are complex and uncertain with some studies predicting net growth due to warming and increased atmospheric $\mathrm{CO}_{2}$ concentrations and others predicting net losses due to shifts in the balance of photosynthesis and respiration, as well as increased disturbances from wind, drought, fires, pests and pathogens that could reduce carbon stocks and offset any increased growth from higher temperatures. Flexible adaptive management 
systems will be essential to maintain and expand the large forest carbon stocks and ensure that the boreal forests of Sweden and Finland remain a stable and growing carbon sink. Sustainable forestry practices and proper enforcement of certification standards can assist in maintaining stable forest carbon stocks.

Furthermore, while this study has focused on carbon, there is a need to consider that forests, while vital for carbon absorption and storage, are complex ecosystems, essential for biodiversity conservation, places for recreation and spiritual renewal, as well as important industries with great economic value. Any consideration of the use of forests for forestry products also needs to balance these sometimes competing needs; decisions as to forest management should not be made on the basis of just one ecosystem service, such as carbon sequestration. In conclusion, any advantage of wood-derived packaging such as beverage cartons depends, at least partly, on the maintenance of carbon stocks in the forests that supply the raw material.

Acknowledgments This paper is based on research funded by The Alliance for Beverage Cartons and the Environment (ACE) UK and the Earthwatch Institute. Any opinions, findings, conclusions or recommendations expressed in this paper are those of the authors and do not necessarily reflect the views of Earthwatch. The authors would like to thank Bryan Foster, Michael Gell, Bill Leverett, Mike Packer and Mark Watson for the useful comments on the original report upon which this paper is based, and to two anonymous reviewers for their comments on an earlier draft of the manuscript.

Open Access This article is distributed under the terms of the Creative Commons Attribution 4.0 International License (http:// creativecommons.org/licenses/by/4.0/), which permits unrestricted use, distribution, and reproduction in any medium, provided you give appropriate credit to the original author(s) and the source, provide a link to the Creative Commons license, and indicate if changes were made.

\section{References}

ACE (2013a) The beverage carton industry in Europe. The Alliance for Beverage Cartons and the Environment. http://www. beveragecarton.eu/en/beverage-cartons-3/our-industry. Accessed 25 July 2013

ACE (2013b) Who produces the beverage carton? The Alliance for Beverage Cartons and the Environment. http://www. beveragecarton.eu/en/beverage-cartons-3/our-industry/producers. Accessed 25 July 2013

Apps MJ, Kurz WA, Beukema SJ, Bhatti JS (1999) Carbon budget of the Canadian forest product sector. Environ Sci Policy 2(1):25-41

Berenguer E, Gardner TA, Ferreira J, Aragão LEOC, Camargo PB, Cerri CE, Durigan M, Oliveira Junior RC, Vieira ICG, Barlow J (2015) Developing cost-effective field assessments of carbon stocks in human-modified tropical forests. PLoS ONE 10(8):e0133139

Bradshaw CJA, Warkentin IG, Sodhi NS (2009) Urgent preservation of boreal carbon stocks and biodiversity. Trends Ecol Evol 24(10): 541-548. doi:10.1016/j.tree.2009.03.019

Brandão M, Heath G, Cooper J (2012) What Can meta-analyses tell us about the reliability of life cycle assessment for decision support? J Ind Ecol 16:S3-S7
Burton PJ, Bergeron Y, Bogdanski BEC, Juday GP, Kuuluvainen T, McAfee BJ, Ogden A, Teplyakov VK, Alfaro RI, Francis DA, Gauthier S, Hantula J (2010) Sustainability of boreal forests and forestry in a changing environment. In: Mery G, Katila P, Galloway $\mathrm{G}$ et al (eds) Forests and society - responding to global drivers of change, vol 25. IUFRO World Series, Tampere, pp 249 282

CEPI (2007) Framework for the development of carbon footprints for paper and board products. Confederation of European Paper Industries, Brussels

Cherubini F, Strømman AH, Hertwich E (2011) Effects of boreal forest management practices on the climate impact of $\mathrm{CO}_{2}$ emissions from bioenergy. Ecol Model 223(1):59-66

Côté WA, Young RJ, Risse KB, Costanza AF, Tonelli JP, Lenocker C (2002) A carbon balance method for paper and wood products. Environ Pollut 116:S1-S6

Curran MA, Mann M, Norris G (2005) The international workshop on electricity data for life cycle inventories. J Clean Prod 13(8):853862

DeLuca TH, Boisvenue C (2012) Boreal forest soil carbon: distribution, function and modelling. Forestry 85(2):161-184

Detzel A, Wellenreuther F, Krüger M (2008) Carbon footprint of milk and juice containers in Spain. Institut für Energieund Umweltforschung, Heidelberg

Dixon RK, Solomon AM, Brown S, Houghton RA, Trexier MC, Wisniewski J (1994) Carbon pools and flux of global forest ecosystems. Science 263(5144):185-190

Eriksson E, Karlsson PE, Hallberg L, Jelse K (2010) Carbon footprint of cartons in Europe - carbon footprint methodology and biogenic carbon sequestration. The Swedish Environmental Research Institute Ltd, Stockholm

EUSTAFOR (2012) European forestry in the face of climate change. European State Forest Association (EUSTAFOR), Brussels

FAO (2010) Global forest resources assessment. Food and Agriculture Organization of the United Nations, Rome

Finér L, Mannerkoski H, Piirainen S, Starr M (2003) Carbon and nitrogen pools in an old-growth, Norway spruce mixed forest in eastern Finland and changes associated with clear-cutting. For Ecol Manag 174(1-3):51-63

Fischlin A, Ayres M, Karnosky D, Kellomäki S, Louman B, Ong C, Plattner G-K, Santoso H, Thompson I, Booth TH, Marcar N, Scholes B, Swanston C, Zamolodchikov D (2009) Future environmental impacts and vulnerabilities. In: Seppala R, Buck A, Katila P (eds) Adaptation of forests and people to climate change, vol 22. IUFRO World Series, Tampere, pp 53-100

FSC (2013) Global FSC certificates: type and distribution. FSC International Center $\mathrm{GmbH}$, Bonn

Garcia-Gonzalo J, Peltola H, Briceno-Elizondo E, Kellomaki S (2007) Changed thinning regimes may increase carbon stock under climate change: a case study from a Finnish boreal forest. Climate Change 81(3-4):431-454

Gaudreault C, Vice K (2011) Summary of the literature on the treatment of paper and paper packaging products recycling in life cycle assessment. National Council for Air and Stream Improvement, Montreal

Gelman V, Hulkkonen V, Kantola R, Nousiainen M, Nousiainen V, PokuMarboah M (2013) Impacts of forest management practices on forest carbon. Helsinki University Centre for Environment, Helsinki

Gower ST (2003) Patterns and mechanisms of the forest carbon cycle. Ann Rev Environ Resour 28(1):169-204

Grant RF, Nalder IA (2000) Climate change effects on net carbon exchange of a boreal aspen-hazelnut forest: estimates from the ecosystem model ecosys. Glob Chang Biol 6(2):183-200

Guinée J, Heijungs R, Voet E (2009) A greenhouse gas indicator for bioenergy: some theoretical issues with practical implications. Int $\mathrm{J}$ Life Cycle Assess 14(4):328-339 
Helin T, Sokka L, Soimakallio S, Pingoud K, Pajula T (2013) Approaches for inclusion of forest carbon cycle in life cycle assessment- $\mathrm{a}$ review. GCB Bioenergy 5(5):475-486

Hellweg S, Milà i Canals L (2014) Emerging approaches, challenges and opportunities in life cycle assessment. Science 344(6188):1109 1113

Holtsmark B (2012) Harvesting in boreal forests and the biofuel carbon debt. Climate Change 112(2):415-428

Holtsmark B (2013) The outcome is in the assumptions: analyzing the effects on atmospheric $\mathrm{CO}_{2}$ levels of increased use of bioenergy from forest biomass. GCB Bioenergy 5(4):467-473

Hudiburg TW, Law BE, Wirth C, Luyssaert S (2011) Regional carbon dioxide implications of forest bioenergy production. Nat Clim Chang 1(8):419-423

Hyvönen R, Ågren GI, Linder S, Persson T, Cotrufo MF, Ekblad A, Freeman M, Grelle A, Janssens IA, Jarvis PG, Kellomäki S, Lindroth A, Loustau D, Lundmark T, Norby RJ, Oren R, Pilegaard K, Ryan MG, Sigurdsson BD, Strömgren M, Van Oijen M, Wallin G (2007) The likely impact of elevated $\left[\mathrm{CO}_{2}\right]$, nitrogen deposition, increased temperature and management on carbon sequestration in temperate and boreal forest ecosystems: a literature review. New Phytol 173(3):463-480

IPCC (2006) Guidelines for National Greenhouse Gas Inventories. IPCC, Kanagawa

ISO (2006a) ISO 14040: environmental management - life cycle assessment-principles and framework. International Organization for Standardization, Geneva

ISO (2006b) ISO 14044: environmental management-life cycle assessment-requirements and guidelines. International Organisation for Standardisation, Geneva

James K (2010) Methodology for assessing the climate change impacts of packaging optimisation under the Courtauld Commitment Phase 2. Waste \& Resources Action Programme, Banbury

James K (2012) An investigation of the relationship between recycling paper and card and greenhouse gas emissions from land use change. Resour Conserv Recycl 67:44-55

Jandl R, Lindner M, Vesterdal L, Bauwens B, Baritz R, Hagedorn F, Johnson DW, Minkkinen K, Byrne KA (2007) How strongly can forest management influence soil carbon sequestration? Geoderma 137(3-4):253-268

Jelse K, Eriksson E, Einarson E (2009) Assessment of consumer packaging for liquid food - results for the Nordic market. The Swedish Environmental Research Institute Ltd, Stockholm

Karjalainen T (1996) Dynamics and potentials of carbon sequestration in managed stands and wood products in Finland under changing climatic conditions. For Ecol Manag 80(1-3):113-132

Kasischke ES, Christensen NL, Stocks BJ (1995) Fire, global warming, and the carbon balance of boreal forests. Ecol Appl 5(2):437-451

Köhl M, Bastup-Birk A, Marchetti M, Cimini D, Corona P, Thorsen BJ, Lasserre B, Pettenella D, Saastamoinen O, Jensen FS (2011) Criterion 3: maintenance and encouragement of productive functions of forests (wood and non-wood). In: Forest Europe, UNECE, FAO (eds) State of Europe's forests 2011. Status and trends in sustainable forest management in Europe. Ministerial Conference on the Protection of Forests in Europe, Oslo, pp 51-64

Kurz WA, Stinson G, Rampley GJ, Dymond CC, Neilson ET (2008) Risk of natural disturbances makes future contribution of Canada's forests to the global carbon cycle highly uncertain. Proc Natl Acad Sci 105(5):1551-1555

Labouze E, Schultze A, Cruypenninck H (2008) Analyses de Cycle de Vie des emballages de Tetra Pak. BIO Intelligence Service, Paris

Lucier A, Ayres M, Karnosky D, Thompson I, Loehle C, Percy K, Sohngen B (2009) Forest responses and vulnerabilities to recent climate change. In: Seppala R, Buck A, Katila P (eds) Adaptation of forests and people to climate change, vol 22. IUFRO World Series, Tampere, pp 29-52
Luyssaert S, Schulze ED, Borner A, Knohl A, Hessenmoller D, Law BE, Ciais P, Grace J (2008) Old-growth forests as global carbon sinks. Nature 455(7210):213-215

Manomet Center for Conservation Sciences (2010) Massachusetts Biomass Sustainability and Carbon Policy Study: Report to the Commonwealth of Massachusetts Department of Energy Resource. Natural Capital Initiative Report, Brunswick, Maine

McKechnie J, Colombo S, Chen JX, Mabee W, Maclean HL (2011) Forest bioenergy or forest carbon? Assessing trade-offs in greenhouse gas mitigation with wood-based fuels. Environ Sci Technol 45(2):789-795

Meyhoff Fry J, Hartlin B, Wallén E, Aumônier S (2010a) Life cycle assessment of example packaging systems for milk: doorstep distribution system. Waste \& Resources Action Programme, Banbury

Meyhoff Fry J, Hartlin B, Wallén E, Aumônier S (2010b) Life cycle assessment of example packaging systems for milk: retail distribution system. Waste \& Resources Action Programme, Banbury

Millard P, Sommerkorn M, Grelet GA (2007) Environmental change and carbon limitation in trees: a biochemical, ecophysiological and ecosystem appraisal. New Phytol 175(1):11-28

Milyukova IM, Kolle O, Varlagin AV, Vygodskaya NN, Schulze ED, Lloyd J (2002) Carbon balance of a southern taiga spruce stand in European Russia. Tellus B 54(5):429-442

Nabuurs GJ, Thürig E, Heidema N, Armolaitis K, Biber P, Cienciala E, Kaufmann E, Mäkipää R, Nilsen P, Petritsch R, Pristova T, Rock J, Schelhaas MJ, Sievanen R, Somogyi Z, Vallet P (2008) Hotspots of the European forests carbon cycle. For Ecol Manag 256(3):194-200

Newell JP, Vos RO (2012) Accounting for forest carbon pool dynamics in product carbon footprints: challenges and opportunities. Environ Impact Assess Rev 37:23-36

Pan YD, Birdsey RA, Fang JY, Houghton R, Kauppi PE, Kurz WA, Phillips OL, Shvidenko A, Lewis SL, Canadell JG, Ciais P, Jackson RB, Pacala SW, McGuire AD, Piao SL, Rautiainen A, Sitch S, Hayes D (2011) A large and persistent carbon sink in the world's forests. Science 333(6045):988-993

Pasqualino J, Meneses M, Castells F (2011) The carbon footprint and energy consumption of beverage packaging selection and disposal. J Food Eng 103(4):357-365

Pingoud K, Pohjola J, Valsta L (2010) Assessing the integrated climatic impacts of forestry and wood products. Silvae Fenn 44(1):155-175

Pregitzer KS, Euskirchen ES (2004) Carbon cycling and storage in world forests: biome patterns related to forest age. Glob Chang Biol 10(12):2052-2077

Profft I, Mund M, Weber GE, Weller E, Schulze ED (2009) Forest management and carbon sequestration in wood products. Eur J For Res 128(4):399-413

Rabl A, Benoist A, Dron D, Peuportier B, Spadaro J, Zoughaib A (2007) How to account for $\mathrm{CO}_{2}$ emissions from biomass in an LCA. Int J Life Cycle Assess 12(5):281-281

Sathre R, O'Connor J (2010) A synthesis of research on wood products \& greenhouse gas impacts (technical report TR-19R), 2nd edn. FPInnovations, Vancouver

Schlamadinger B, Marland G (1996) The role of forest and bioenergy strategies in the global carbon cycle. Biomass Bioenergy 10(5-6): 275-300

Schulze ED, Lloyd J, Kelliher FM, Wirth C, Rebmann C, Luhker B, Mund M, Knohl A, Milyukova IM, Schulze W, Ziegler W, Varlagin AB, Sogachev AF, Valentini R, Dore S, Grigoriev S, Kolle O, Panfyorov MI, Tchebakova N, Vygodskaya NN (1999) Productivity of forests in the Eurosiberian boreal region and their potential to act as a carbon sink - a synthesis. Glob Chang Biol 5(6): $703-722$

Schulze E-D, Körner C, Law BE, Haberl H, Luyssaert S (2012) Large-scale bioenergy from additional harvest of forest biomass is neither sustainable nor greenhouse gas neutral. GCB Bioenergy 4(6):611-616 
Scientific Committee EEA (2011) Opinion of the EEA Scientific Committee on greenhouse gas accounting in relation to bioenergy. European Environment Agency, Copenhagen

Searchinger TD (2010) Biofuels and the need for additional carbon. Environ Res Lett 5(2):024007

SEPA (2012) National inventory report Sweden. Swedish Environmental Protection Agency, Stockholm

Smith P, Smith J, Wattenbach M, Meyer J, Lindner M, Zaehle S, Hiederer R, Jones RJA, Montanarella L, Rounsevell M, Reginster I, Kankaanpää S (2006) Projected changes in mineral soil carbon of European forests, 1990-2100. Can J Soil Sci 86(Special Issue):159-169

Statistics Finland (2012) Greenhouse gas emissions in Finland 1990 2010: national inventory report under the UNFCCC and the Kyoto protocol. Statistics Finland, Helsinki

Thornley JHM, Cannell MGR (2000) Managing forests for wood yield and carbon storage: a theoretical study. Tree Physiol 2(7):477-484

Thurig E, Kaufmann E (2010) Increasing carbon sinks through forest management: a model-based comparison for Switzerland with its Eastern Plateau and Eastern Alps. Eur J For Res 129(4):563-572

Villanueva A, Wenzel H (2007) Paper waste - Recycling, incineration or landfilling? A review of existing life cycle assessments. Waste Manage 27(8):S29-S46

von Falkenstein E, Detzel A, Wellenreuther F (2009) LCA studies on beverage cartons and alternative packaging. Institut für Energieund Umweltforschung, Heidelberg von Falkenstein E, Wellenreuther F, Detzel A (2010) LCA studies comparing beverage cartons and alternative packaging: can overall conclusions be drawn? Int J Life Cycle Assess 15(9): 938-945

Wellenreuther F, von Falkenstein E, Detzel A (2012) Comparative life cycle assessment of beverage cartons combiblocSlimline and combiblocSlimline EcoPlus for UHT milk. Institut für Energieund Umweltforschung, Heidelberg

White MK, Gower ST, Ahl DE (2005) Life cycle inventories of roundwood production in northern Wisconsin: Inputs into an industrial forest carbon budget. For Ecol Manage 219(1):13-28. doi:10. 1016/j.foreco.2005.08.039

Wigrup I (ed) (2012) Swedish statistical yearbook of forestry. Swedish Forest Agency, Jönköping

Xie M, Li L, Qiao Q, Sun Q, Sun T (2011) A comparative study on milk packaging using life cycle assessment: from PA-PE-Al laminate and polyethylene in China. J Clean Prod 19(17-18): 2100-2106

Ylitalo E (ed) (2012) Finnish statistical yearbook of forestry, vol 6, vol 6. Finnish Forest Research Institute, Helsinki

Zanchi G, Pena N, Bird N (2010) The upfront carbon dept of bioenergy. Joanneum Research, Graz

Zimov SA, Schuur EAG, Chapin FS (2006) Permafrost and the global carbon budget. Science 312(5780):1612-1613 